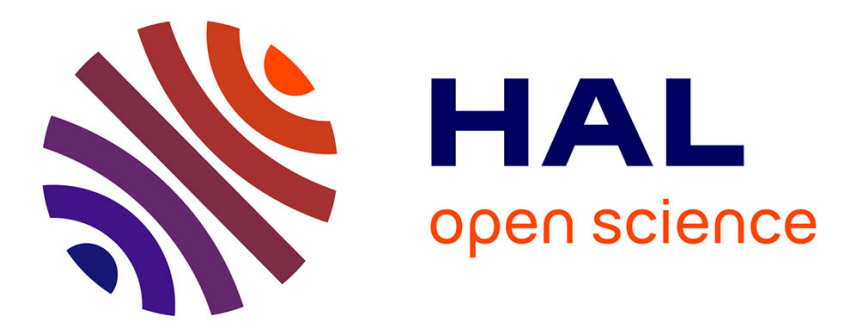

\title{
Improvement of Ni phytoextraction by Alyssum murale and its rhizosphere microbial activities by applying nitrogen fertilizer
}

Ali Kanso, Sabine Azoury, E Benizri, Ahmad Kobaissi, Guillaume Echevarria, Catherine Sirguey

\section{To cite this version:}

Ali Kanso, Sabine Azoury, E Benizri, Ahmad Kobaissi, Guillaume Echevarria, et al.. Improvement of Ni phytoextraction by Alyssum murale and its rhizosphere microbial activities by applying nitrogen fertilizer. Ecological Research, 2018, 33 (4), pp.811-821. 10.1007/s11284-018-1630-0 . hal-02025846

\section{HAL Id: hal-02025846 https://hal.science/hal-02025846}

Submitted on 19 Feb 2019

HAL is a multi-disciplinary open access archive for the deposit and dissemination of scientific research documents, whether they are published or not. The documents may come from teaching and research institutions in France or abroad, or from public or private research centers.
L'archive ouverte pluridisciplinaire HAL, est destinée au dépôt et à la diffusion de documents scientifiques de niveau recherche, publiés ou non, émanant des établissements d'enseignement et de recherche français ou étrangers, des laboratoires publics ou privés. 


\section{Improvement of Ni phytoextraction by Alyssum murale and its rhizosphere microbial activities by applying nitrogen fertilizer}

Received: 16 October 2017 / Accepted: 14 May 2018

(C) The Ecological Society of Japan 2018
Keywords Nickel · Hyperaccumulator · Agromining · Bacterial community $\cdot$ Microbial enzymatic activities

\section{Introduction}

The presence of heavy metals at concentrations higher than that of geochemical background levels has become an increasingly serious concern, posing risks to the environment and human health (Biney et al. 1994). One of these elements, nickel (Ni), can be present in soils in concentrations ranging from 2000 to $10,000 \mu \mathrm{g} \mathrm{g}^{-1}$, the highest levels being encountered on ultramafic rocks such as serpentine, characterized by naturally high $\mathrm{Ni}$ concentrations (Chaney et al. 2008; van der Ent et al. 2013)

Soil metal contamination led to the development of many clean-up technologies. Among them, the most commonly used are physicochemical techniques which are generally expensive and may have deleterious effects on the physical, chemical and biological soils properties (Ma et al. 2009; Glick 2010). For these reasons, the remediation of most contaminated sites by these techniques has not evolved rapidly (Cunningham and $\mathrm{Ow}$ 1996). In recent years, phytoremediation techniques have been developed (Chaney et al. 2007, 2008). Their most striking feature is that they are acceptable among the public, relatively inexpensive and that they offer an opportunity to improve the biological and physicochemical properties of soils (Pulford and Watson 2003). Phytoremediation is based on the principle of combining the use of plants and their rhizosphere associated microorganisms to reduce the toxicity of pollutants such as trace elements (Khan 2005). Among the various techniques, phytoextraction represents an innovative method to remediate contaminated or naturally metalrich sites. This technique relies on the absorption of metals by a hyperaccumulator plant, and their translocation into the harvestable aerial parts of the plant (Lasat 2002; Bani et al. 2010). However, the main limiting factors the phytoextraction efficiency could be the 
low biomass production of hyperaccumulator plants due to the generally limited soil fertility (low nitrogen, potassium and phosphorus nutrient status) (Bani et al. 2007; Boyd and Jaffré 2009; Tumi et al. 2012). Consequently, many studies aimed to improve the plant biomass production by supplying either organic or inorganic amendments to soils (Bani et al. 2015). Indeed, over the past decade, several studies have highlighted that addition of mineral NPK amendments increased crop yields, which could reach at least $20 \mathrm{tha}^{-1}$ of dry biomass and $400 \mathrm{~kg} \mathrm{ha}^{-1}$ of extracted $\mathrm{Ni}$ on serpentine soils (Chaney et al. 2007). Concerning organic amendments, such as compost or manure, they are known to improve fertility as well as the physical properties of soils (Vangronsveld et al. 2009). In addition, manure can increase metal mobility due to its high content of soluble and reactive organic matter, which can complex the metals (Tandy et al. 2009; Álvarez-López et al. 2016). Manure application increases hyperaccumulator plant growth and Ni phytoextraction yield but can lead to the dilution of $\mathrm{Ni}$ in shoots depending on the level of addition (Álvarez-López et al. 2016).

Moreover, the effectiveness of hyperaccumulation depends on the interaction of the roots with the rhizosphere microorganisms (Abou-Shanab et al. 2003). The rhizosphere, compared to bulk soil, is characterized by higher concentrations of nutrients and labile organic carbon (Duineveld et al. 2001). Consequently, it represents a unique 'hot spot' in terms of microbial ecology because soil microorganisms are stimulated by root activity (Hinsinger et al. 2006). Indeed, their localization, in this particular environment, allows microorganisms to benefit from the rhizodeposits (root exudates) which provide them nutrients and energy and eventually help to reinforce the growth of the hyperaccumulators plant by various mechanisms ( $\mathrm{Ma}$ et al. 2009; Durand et al. 2016). Consequently, the structure and the diversity of the rhizosphere microbial community, as shown by numerous studies, are affected by the cultivated plant species due to the secretion of various root exudates (Smalla et al. 2001; Baudoin et al. 2003). Conversely, soil microorganisms drive, via their enzyme activities, the cycling of all major elements. These microbial enzymes play an important role at the soil level since they are involved in the biogeochemical cycles of carbon, nitrogen, sulfur, phosphorus and other nutrients (Caldwell 2005; Kibblewhite et al. 2008). This cycling affects the structure and functions of soil ecosystem as well as the ability of soils to provide ecosystem services. Soil enzyme activities have been reported to provide a unique integrative biochemical assessment of soil functions and conditions (Naseby and Lynch 2002) and to be useful indicators of soil functional diversity (Bending et al. 2004; Sowerby et al. 2005; Epelde et al. 2009). These activities of soil microorganisms are influenced by various abiotic parameters (e.g. soil type, nutrient status, $\mathrm{pH}$, texture, organic matter content, moisture) and their interactions on the one hand, and by plant factors (e.g. plant species, age, root zone) on the other hand (Baudoin et al. 2003).

However, among abiotic factors, the presence of heavy metals in soils also modulates the microbial activities and their interactions (Krumins et al. 2015). The interaction of metals with native soil communities and their activities is an important area of research as scientists strive to understand the effects of metal pollution or enrichment on soil properties and microbial activities (Hagmann et al. 2015; Lopez et al. 2017). Depending on the study, the effects of trace elements on rhizospheric enzyme activities are complex and contrasting effects can be observed (Egamberdieva et al. 2011). However, some soil microorganisms, including bacteria, archaea and fungi, are capable of withstanding high concentrations of metals (do Nascimento and Xing 2006).

Our experiment studied the effect of $\mathrm{N}$ additions on the cultivation of a Ni hyperaccumulator plant, Alyssum murale (Waldst. \& Kit-Brassicaceae), with the aim of remediating a soil artificially contaminated with two different concentrations of $\mathrm{Ni}\left(40\right.$ and $\left.80 \mathrm{mg} \mathrm{kg}^{-1}\right)$. In this regard, we wish to investigate the effect of mineral nitrogen fertilization on (1) plant biomass and phytoextraction efficiency, and (2) on the soil microbial properties, particularly the numbers of the cultivable bacterial communities and the associated microbial enzymatic activities.

\section{Methods}

\section{Soil sampling}

The 0-30 cm depth topsoil was collected from a natural site in Lebanon $\left(33^{\circ} 11^{\prime} 34.59^{\prime \prime} \mathrm{N}, 35^{\circ} 24^{\prime} 34.92^{\prime \prime} \mathrm{E}\right)$ and then sieved to $5 \mathrm{~mm}$. Preliminary analyses such as soil texture (SOP METH004.00), total calcium carbonate (NF ISO 10,693), pH (NF ISO 10390), electrical conductivity (AFNOR X 31-113) and organic material (ASTM D 2974) were performed (Table 1). The soil is clayey with an alkaline $\mathrm{pH}$ but a low percentage of total carbonate. The electrical conductivity is low. This soil, as predicted, has a low percentage of organic matter because it was selected from an uncultivated area and devoid of plant residues.

\section{Plant cultivation}

A column system (Polyvinyl chloride cylindrical tubes of $30 \mathrm{~cm}$ height and $15 \mathrm{~cm}$ diameter) was prepared for culturing. These columns were filled with $5 \mathrm{~kg}$ of soil (dry weight basis). The soil was artificially enriched with nickel sulfate $\left(\mathrm{NiSO}_{4} \cdot 6 \mathrm{H}_{2} \mathrm{O}\right)$ to reach two different soil bulk concentrations: 40 and $80 \mathrm{mg} \mathrm{Ni} \mathrm{kg}{ }^{-1}$ dry soil (Ni40 and Ni80 treatments, respectively). These concentrations were chosen to guarantee both a limited 
Table 1 Physicochemical characteristics of the natural soil used in the experiments

\begin{tabular}{llc}
\hline Parameter & Unit & Value \\
\hline Sand & $\%$ & 23.4 \\
Silt & $\%$ & 15.3 \\
Clay & $\%$ & 61.2 \\
Total carbonate & $\%$ & 0.30 \\
Electrical conductivity & $\mathrm{mS} \mathrm{cm}{ }^{-1}$ & 0.72 \\
pH & & 7.96 \\
Organic matter & $\%$ & 0.70 \\
\hline
\end{tabular}

toxicity to the soil microbial community and a sufficient $\mathrm{Ni}$ availability for phytoextraction. That is why, values were selected in the concentration range $(0$ to $90 \mathrm{mg}$ $\mathrm{Ni} \mathrm{kg}{ }^{-1}$ supplied as $\mathrm{NiSO}_{4}$ ) studied by Saad et al. (2016) to evaluate the nitrogen fixation and growth of Lens culinaris var. Beluga (Fabaceae), France as affected by nickel availability. The soil was thoroughly homogenized and incubated at room temperature for 15 days after a $70 \%$ water retention capacity adjustment.

Seeds of $A$. murale Waldst. \& Kit were harvested from a natural ultramafic site near Trigona (Thessaly, Greece) in August 2014. One seed per tube was sown $(1 \mathrm{~cm}$ deep). The plants were cultivated in a growth chamber over a period of 5 months under controlled conditions: $16 \mathrm{~h}$ photoperiod, $22{ }^{\circ} \mathrm{C} / 18{ }^{\circ} \mathrm{C}$ day/night temperature, $70 \%$ of relative humidity and a photosynthetic photon flux density of $350 \mu \mathrm{mol} \mathrm{m} \mathrm{m}^{-2} \mathrm{~s}^{-1}$. The tubes were watered with distilled water every 3 days up to $70 \%$ of soil water holding capacity. Two weeks after sowing, the solution of $\mathrm{NH}_{4}-\mathrm{NO}_{3}$ was surface applied to half of the columns. Each column received $0.3 \mathrm{~g}$ of $\mathrm{NH}_{4}-\mathrm{NO}_{3}$ dissolved in $50 \mathrm{~mL}$ distilled water (corresponding to $60 \mathrm{~kg} \mathrm{~N} \mathrm{ha}^{-1}$ ). So, the combination of these two factors makes it possible to obtain four treatments: non-fertilized (Ni40-NF and Ni80-NF) and $\mathrm{N}$ fertilized (Ni40-F and Ni80-F) Ni contaminated soils. The experiment had a factorial randomized complete block design with three replicates of the four treatments.

\section{Plant harvest and analysis}

At the end of the experiment, plants were collected. Fresh shoots were carefully washed with deionized water and then dried in the oven at $70{ }^{\circ} \mathrm{C}$ for $72 \mathrm{~h}$ to allow dry weight measurement. The samples were ground and homogenized. For metal analysis, a subsample $(0.5 \mathrm{~g})$ of plant tissue was acid-digested at $95{ }^{\circ} \mathrm{C}$ in $2.5 \mathrm{ml}$ of concentrated $\mathrm{HNO}_{3}$ and $5 \mathrm{ml}$ of $\mathrm{H}_{2} \mathrm{O}_{2}(30 \%)$. The final solutions were filtered at $0.45 \mu \mathrm{m}$ and diluted with deionized water to reach $25 \mathrm{ml}$. Metal concentrations in the solution were measured with an inductively coupled plasma mass spectrometry (ICP-MS; Thermo Fisher Scientific X Series 2, USA). Control material from Noccaea caerulescens (J.Presl \& C.Presl-Brassicaceae) with known compositions (internal analyses carried out by INRA-USRAVE, Villenave d'Ornon, France), as well as a certified solution $\left(\right.$ EU-H $_{4}$, SCP Science, Courtaboeuf, France) were included in all analyses for quantitative verification of the results.

\section{Bacterial densities}

At harvest, rhizosphere soil, considered as the soil strongly adhering to the roots and collected within the space exploited by the roots was collected (García et al. 2005). The soil particles loosely bound on the roots were shaken off and discarded. The remaining soil still attached to the roots (hence forth referred to as the rhizosphere soil) was swept off with a brush and collected. Care was taken to avoid cross contamination between different samples. A sample of $10 \mathrm{~g}$ of fresh rhizosphere soil was dropped into a flask containing $100 \mathrm{ml}$ of $\mathrm{NaCl}$ buffer $9 \%\left(0.15 \mathrm{~mol} \mathrm{l}^{-1}\right)$. All the flasks were then placed on an orbital shaker $(17 \mathrm{rpm})$ for $30 \mathrm{~min}$. Then, a $1-\mathrm{ml}$ aliquot per each sample was transferred into a sterile test tube previously filled with $9 \mathrm{ml} \mathrm{NaCl}$. Microbial suspensions were serially diluted and the dilutions $\left(10^{-2}\right.$ $10^{-7}$ ) were used for the determination of the number of cultivable bacteria (i.e., number of colony-forming units (CFU)), by spread-plating them onto nutrient agar medium (NA) (M001 from Himedia-India) supplemented with amphotericin B solution to avoid any fungal strain development $(0.25 \mu \mathrm{g}$ of amphotericin B per $\mathrm{ml})$. The agar plates were then incubated in the dark at $28{ }^{\circ} \mathrm{C}$ for 10 days. The moisture content of the soil collected as "rhizosphere soil" using a brush was measured before making the dilutions with $\mathrm{NaCl}$ solutions. The number of the cultivable bacteria was expressed as CFU $\mathrm{g}^{-1}$ of soil dry weight.

\section{Microbial enzymatic activities}

Urease activity was measured according to the method of Tabatabai and Bremner (1972). Arylsulfatase, $\beta$-glucosidase and alkaline phosphatase activities were determined using $5 \mathrm{mM}$ pNP-sulfate, $5 \mathrm{mM}$ pNP- $\beta$-Dglucopyranoside and $5 \mathrm{mM}$ pNP-phosphate, respectively (Sigma-Aldrich, France) according to the modified protocol of Deng et al. (2012). Substrates of arylsulfatase and $\beta$-glucosidase were prepared in sodium acetate buffer $(0.5 \mathrm{M}, \mathrm{pH} 5.8)$ whilst substrate of alkaline phosphatase was prepared in Tris $\mathrm{HCl}$ buffer $(0.1 \mathrm{M}, \mathrm{pH}$ 8). Four grams of fresh soil were incubated with $0.5 \mathrm{ml}$ toluene for $10 \mathrm{~min}$ before adding $50 \mathrm{ml}$ of distilled water. The mix was then homogenized with a polytron for $25 \mathrm{~s}$. Four hundred $\mu \mathrm{l}$ were immediately sampled and put in a $2 \mathrm{ml}$ microtube then $1 \mathrm{ml}$ of the adequate substrate was added. Samples were incubated at $37^{\circ} \mathrm{C}$ for $2 \mathrm{~h}$. The reaction was stopped by adding $250 \mu \mathrm{l}$ of $1 \mathrm{M} \mathrm{NaOH}$ solution. The blanks were realized by adding the substrate after the addition of the $\mathrm{NaOH}$. Microtubes were then centrifuged for $2 \mathrm{~min}$ at $13,000 \mathrm{~g}$ and $200 \mu \mathrm{l}$ were transferred on a microplate in 
order to read absorbance at $400 \mathrm{~nm}$ on a microplate reader (Biotek Instruments, Synergy HT, USA). In order to calculate the enzymatic activities, readings were compared to a p-Nitrophenol standard curve.

\section{Statistical analysis}

All statistical analyses were performed using R v3.1.1 with the lme, ade4 and Factomine R packages. When necessary, data were log-transformed in order to improve normality and variance homogeneity of residues. The relationships between variables were then assessed using principal component analysis (PCA) and correlation tests were performed using the Spearman method. Analyses of variance for plant and soil parameters were analyzed by a two-way ANOVA with fixed effect (type I $F$ statistics). Post hoc tests were performed using the Tukey method.

\section{Results}

Plant growth, nutritional status and Ni uptake

Five months after sowing, the effects of both $\mathrm{Ni}$ contamination and $\mathrm{N}$ fertilizer on $A$. murale growth and $\mathrm{Ni}$ uptake by this hyperaccumulator plant were measured. A. murale exceeded the Ni hyperaccumulation threshold value of $1000 \mathrm{mg} \mathrm{kg}^{-1}$ whatever the $\mathrm{Ni}$ addition level. However, there was no significant effect of the soil $\mathrm{Ni}$ concentration on A. murale shoots dry weight (Table 2). Conversely, a positive effect of $\mathrm{N}$ application was observed as the shoot dry weight was significantly increased by, respectively 23 and $29 \%$ in Ni40 and Ni80 treatments after the addition of $\mathrm{N}$ fertilizer (Fig. 1a).

With regard to plant $\mathrm{Ni}$ concentration in shoot tissues, analysis of variance highlighted a significant effect of both $\mathrm{Ni}$ and $\mathrm{N}$ treatments as well as a significant interaction between treatments (Table 2). Indeed, the increase of $\mathrm{Ni}$ concentration in soil from 40 to $80 \mathrm{mg}$ $\mathrm{kg}^{-1}$ led to a significant increase of the shoot Ni concentration by a factor of 2.6 in the fertilized plants only (Fig. 1b). Similar results were obtained concerning the quantity of Ni extracted per pot (Fig. 1c, Table 2). A significant increase by $60 \%$ was observed in Ni80-F compared to Ni40-F.

Likewise, $\mathrm{N}$ application significantly increased $\mathrm{Ni}$ concentration in the shoots by, respectively 80 and $158 \%$ in Ni40 and Ni80 treatments (Fig. 1b). In addition, the amount of extracted $\mathrm{Ni}$ was significantly higher

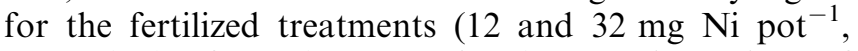
respectively for Ni40-F and Ni80-F) than that of unfertilized (9 and $16 \mathrm{mg} \mathrm{pot}^{-1}$, respectively for Ni40NF and Ni80-NF) (Fig. 1c).

Regarding the nutritional status of the plants at the end of the experiment (K, P, S and Ca content; Fig. 2), no significant difference was observed whatever the soil

Table 2 Analyses of variance for plant parameters accounted for Ni and nitrogen treatments and the interaction between both

\begin{tabular}{lllllllcc}
\hline Source & $d f$ & SDB & K & P & S & Ca & Ni & QNi \\
\hline Nickel & 1 & 0.14 & 0.34 & 0.28 & 0.02 & 0.04 & $10.3^{*}$ \\
Nitrogen & 1 & $135^{* * *}$ & 3.42 & 0.44 & 0.02 & 0.27 & $54.9^{* * *}$ & $99.3^{* * * *}$ \\
Nickel x Nitrogen & 1 & 1.8 & 0.6 & 0.42 & 0.01 & 2.89 & $7.27^{*}$ \\
Residuals & 8 & & & & & & & $11.9^{* *}$ \\
\hline
\end{tabular}

The table shows test statistics with $\mathrm{F}$ values. Significant level: ${ }^{*} P<0.05 ; * * P<0.01 ; * * * P<0.001$

$S D B$ shoot dry biomass, $K, P, S, C a, N i$ plant element concentration, $Q N i$ quantity of Ni extracted

(a)

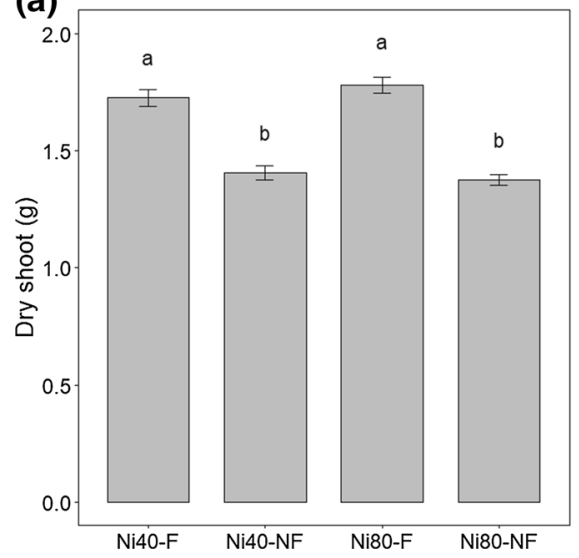

(b)

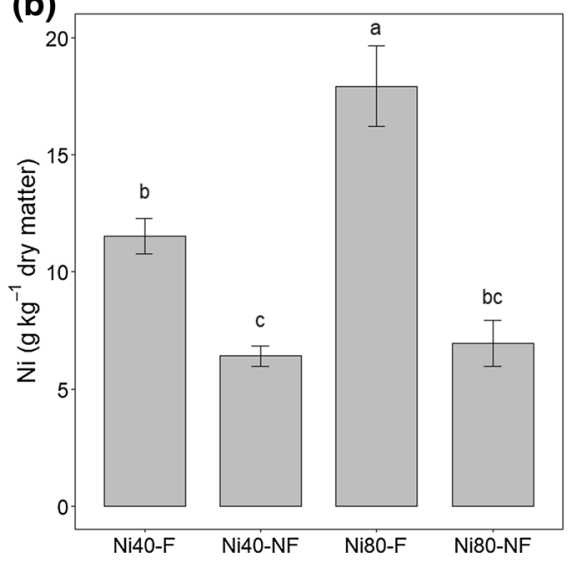

(c)

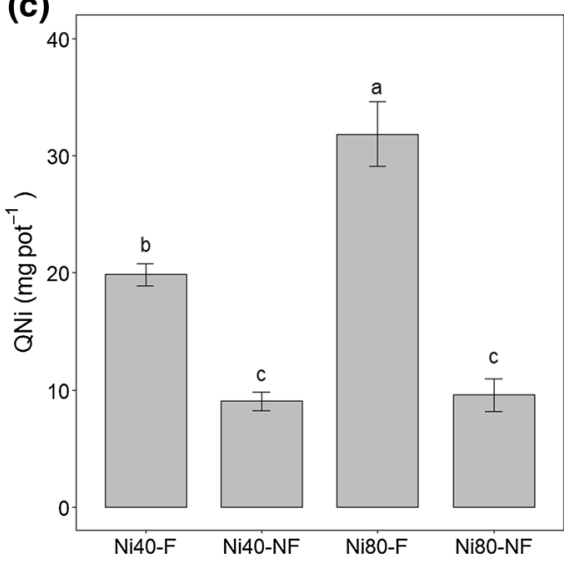

Fig. 1 Variation of a dry shoot weight, b Ni concentration, and c QNi (quantity of Ni) in Alyssum murale shoots according to the soil $\mathrm{Ni}$ concentration ( $\mathrm{Ni40}$ and $\mathrm{Ni} 80$ ) and the $\mathrm{N}$ supply

( $F$ fertilized, $N F$ unfertilized). Results are represented by means with their standard error. Different letters indicate statistical difference $(P<0.05$, Tukey test, $n=3)$ 

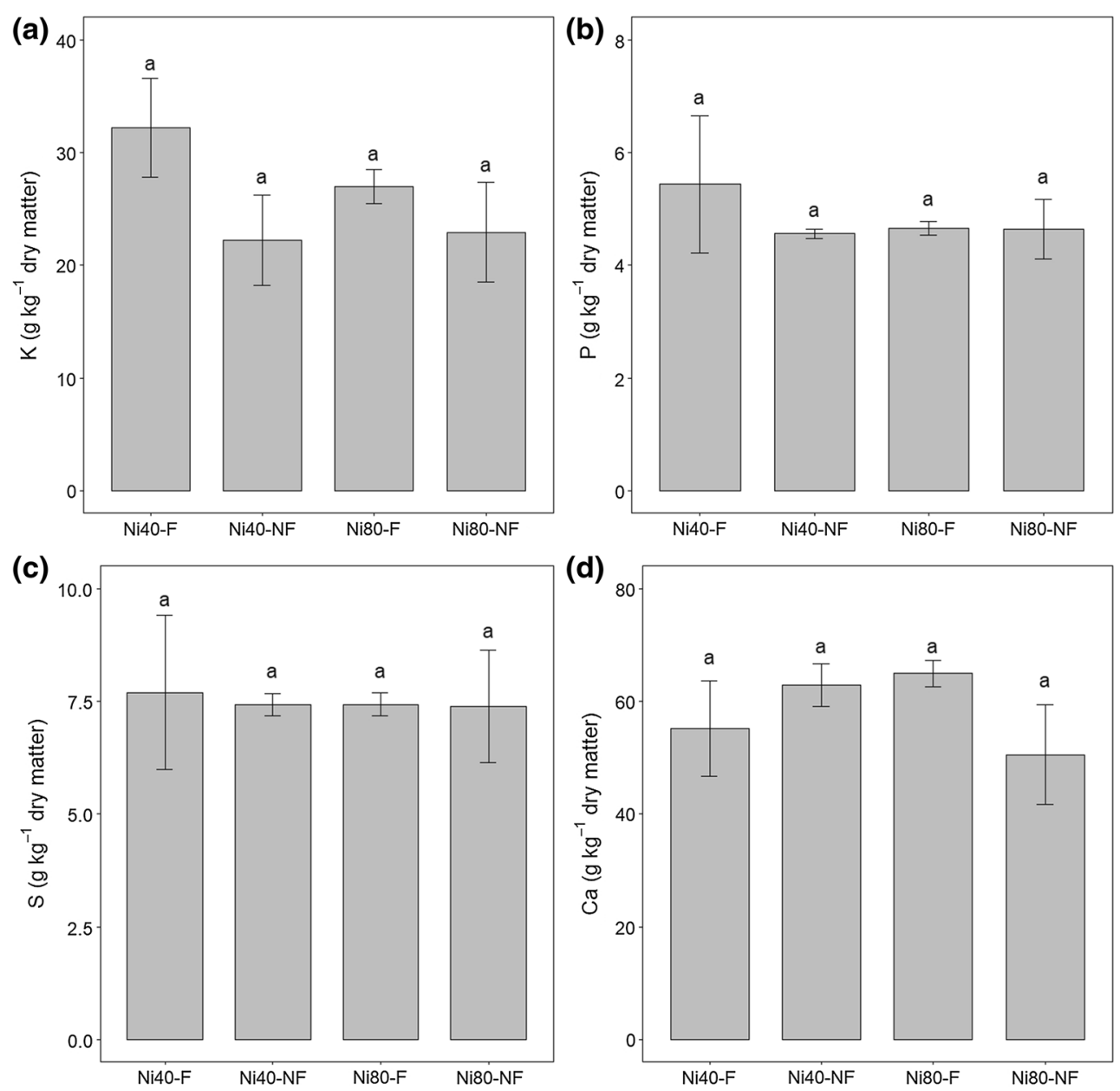

Fig. 2 Variation of a potassium, b phosphorus, c sulfur and d calcium concentrations in Alyssum murale shoots according to the soil $\mathrm{Ni}$ concentration ( $\mathrm{Ni40}$ and $\mathrm{Ni80}$ ) and the $\mathrm{N}$ supply

Ni concentration or the N supply (Table 2)., it was observed a global tendency of a greater element content for the fertilized treatments in comparison with those unfertilized (Electronic supplementary material (ESM), Table S1).

\section{Rhizosphere properties}

\section{pH of the rhizosphere soil}

The analysis of rhizosphere soil revealed a small significant decrease of soil $\mathrm{pH}$ by 0.3 unit in average with response to added $\mathrm{Ni}$ concentration without any significant effect of $\mathrm{N}$ application (Fig. 3, Table 3).

\section{Soil bacterial densities}

The effect of soil Ni concentration and $\mathrm{N}$ supply on the bacterial densities is presented in Fig. 4. Variance analysis revealed a significant effect of both $\mathrm{Ni}$ and $\mathrm{N}$ treatments as well as an interaction effect between

( $F$ fertilized, $N F$ unfertilized). Results are represented by means with their standard error. Different letters indicate statistical difference $(P<0.05$, Tukey test, $n=3)$

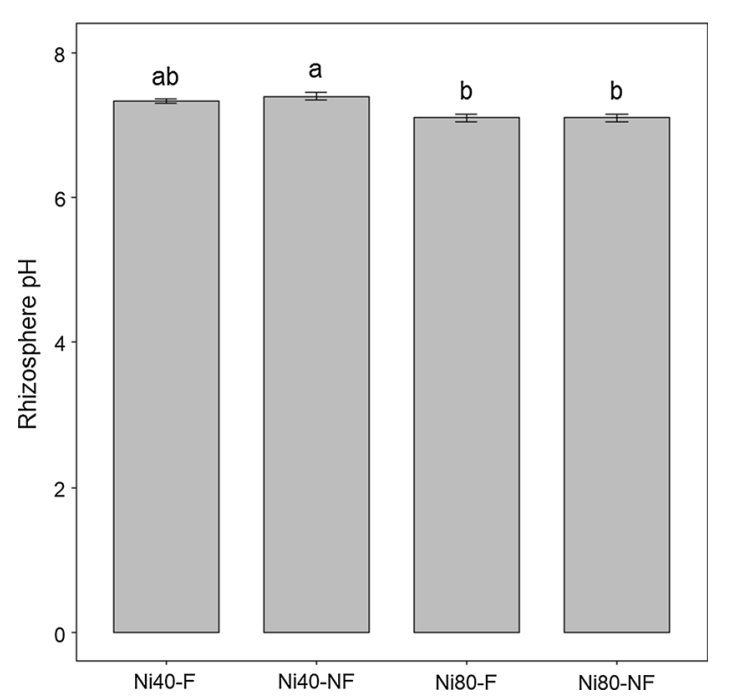

Fig. 3 Variation of rhizosphere soil $\mathrm{pH}$ according to the soil $\mathrm{Ni}$ concentration (Ni40 and Ni80) and the $\mathrm{N}$ supply ( $F$ fertilized, $N F$ unfertilized). Results are represented by means with their standard error. Different letters indicate statistical difference $(P<0.05$, Tukey test, $n=3$ ) 
Table 3 Analyses of variance for soil parameters accounted for $\mathrm{Ni}$ and $\mathrm{N}$ treatments and the interaction between both

\begin{tabular}{llllllc}
\hline Source & $d f$ & BacTot & URE & AP & AS & $\beta$ GLU \\
\hline Nickel & 1 & $168^{* * *}$ & $23.4^{* *}$ & 0.75 & 0.09 & 0.26 \\
Nitrogen & 1 & $320^{* * *}$ & $42.4^{* * *}$ & 0.64 & 0.00 & 0.03 \\
Nickel x Nitrogen & 1 & $6.01^{*}$ & 0.26 & 1.37 & 0.60 & 0.06 \\
Residuals & 8 & & & & & 0.40 \\
\hline
\end{tabular}

The table shows test statistics with $\mathrm{F}$ values. Significant level: $* P<0.05 ; * * P<0.01 ; * * * P<0.001$

BacTot total cultivable bacteria, $U R E$ urease activity, $A P$ alkaline phosphatase activity, $A S$ arylsulfatase activity, $\beta G L U$ betaglucosidase activity

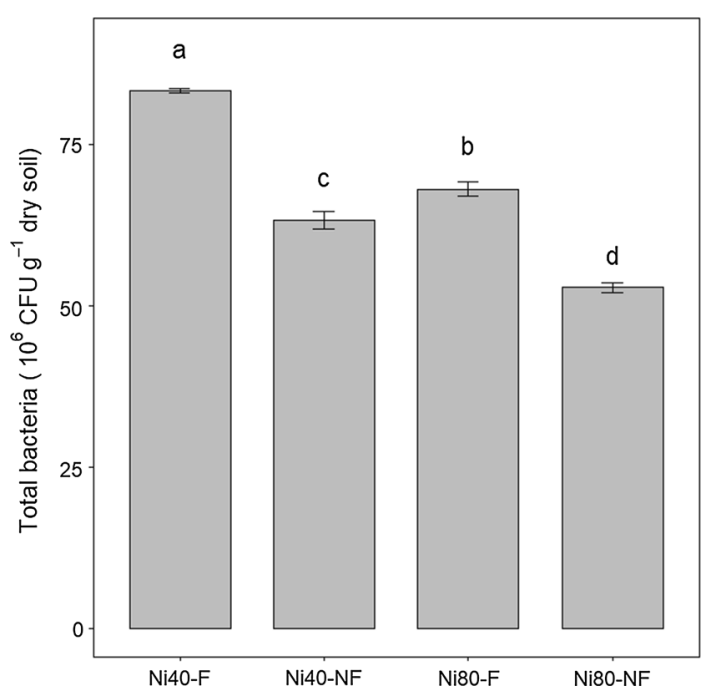

Fig. 4 Number of total cultivable bacteria according to the soil $\mathrm{Ni}$ concentration ( $\mathrm{Ni40}$ and $\mathrm{Ni} 80)$ and the $\mathrm{N}$ supply ( $F$ fertilized, $N F$ unfertilized). Results are represented by means with their standard error. Different letters indicate statistical difference $(P<0.05$, Tukey test, $n=3$ )

treatments (Table 3). Increasing soil Ni concentration from 40 to $80 \mathrm{mg} \mathrm{kg}^{-1}$ significantly decreased the numbers of total bacteria by 18 and $16 \%$, respectively in the fertilized and unfertilized soils. A greater bacterial density was noticed in $\mathrm{N}$-fertilized treatments, as shown by the significant increase of 32 and $29 \%$ respectively in Ni40-F and Ni80-F treated soils.

\section{Soil enzymatic activities}

Figure 5 presents the values of the selected enzymes chosen for their role in the biogeochemical cycle of $\mathrm{C}, \mathrm{N}$, $\mathrm{P}$ and S. Variance analysis showed a significant effect of both $\mathrm{Ni}$ and $\mathrm{N}$ treatments without significant interaction (Table 3). Increasing soil $\mathrm{Ni}$ concentration from 40 to $80 \mathrm{mg} \mathrm{kg}^{-1}$ significantly decreased soil urease activity by an average of $22 \%$. Conversely, the addition of mineral nitrogen led to a significant increase in urease activity by an average of $30 \%$. As a consequence, $\mathrm{N}$ fertilization alleviated the negative effect of increased soil Ni concentration as shown by the higher urease activity in Ni80-F compared to Ni40-NF (Electronic supplemen- tary material (ESM), Table S2). Concerning alkaline phosphatase, $\beta$-glucosidase and arylsulfatase, enzymes belonging respectively to the $\mathrm{P}, \mathrm{C}$ and $\mathrm{S}$ geochemical cycles, the results showed a non-significant variation of their concentrations regardless of the different $\mathrm{Ni}$ and $\mathrm{N}$ treatments. On average, the enzyme activity was respectively $1.15,2.20$ and $12.1 \mu \mathrm{g}$ p-nitrophenol $\mathrm{g}^{-1}$ soil $\mathrm{h}^{-1}$ for arylsulfatase, alkaline phosphatase and $\beta$ glucosidase for all treatments.

\section{Relationships between plant and soil parameters}

The correlations among soil and plant parameters are reported in Table 4. Shoot dry biomass (SDB) was strongly positively correlated with total bacteria and urease activity $(R=0.73)$ whereas plant $\mathrm{K}$ content was weakly positively correlated to total bacteria $(R=0.52)$. Apart the already mentioned correlations, it is to be noticed that SDB was also strongly positively correlated to plant $\mathrm{Ni}$ content $(R=0.82)$. Finally, regarding the relationships between soil parameters, two strong correlations were found, on one hand between total bacteria and urease activity $(R=0.92)$ and on the other hand between alkaline phosphatase and $\beta$-glucosidase activities $(R=0.78)$. A Principal Component Analysis (PCA) has been run with the data (Fig. S1). It confirmed that treatments separated in three statistically different groups along a gradient of both soil Ni concentration and $\mathrm{N}$ supply: Ni80-NF, Ni80-F/Ni40-NF and $\mathrm{Ni}-40-\mathrm{F}$.

\section{Discussion}

\section{Fertilisation effects on Ni phytoextraction}

Concerning the variation of $\mathrm{pH}$ in the rhizosphere of $A$. murale, the addition of $\mathrm{NiSO}_{4}$ to the soil induced a significant $\mathrm{pH}$ decrease. Similar results were observed by Saad et al. (2016) after increasing additions of $\mathrm{NiSO}_{4}$ to an agricultural topsoil. This drop in $\mathrm{pH}$ is probably due to the complexation of $\mathrm{Ni}^{2+}$ to soil surface sites and to the exchange of $\mathrm{Ni}^{2+}$ with $\mathrm{H}^{+}$from the soil exchange complex, both processes releasing surface $\mathrm{H}^{+}$ions to soil solution. However, the reduction in $\mathrm{pH}$ did not af- 

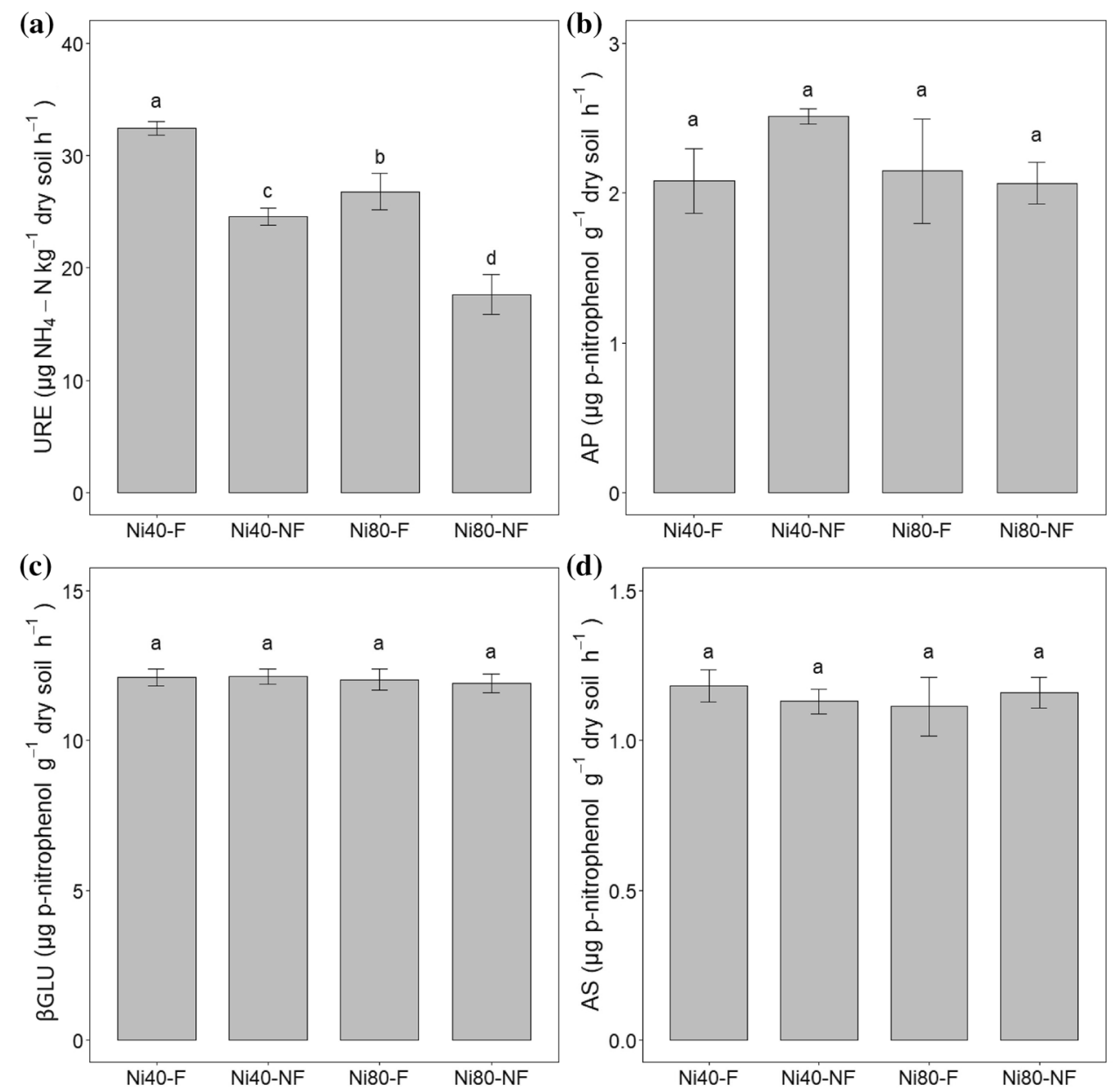

Fig. 5 Variation of a urease (URE), b alkaline phosphatase (AP), c $\beta$-glucosidase $(\beta \mathrm{GLU})$ and $\mathbf{d}$ arylsulfatase (AS) concentrations according to the soil $\mathrm{Ni}$ concentration (Ni40 and Ni80) and the $\mathrm{N}$

supply ( $F$ fertilized, $N F$ unfertilized). Results are represented by means with their standard error. Different letters indicate statistical difference $(P<0.05$, Tukey test, $n=3)$

Table 4 Correlation matrix between plant and soil parameters

\begin{tabular}{|c|c|c|c|c|c|c|c|c|c|c|c|c|}
\hline & \multirow[t]{2}{*}{$\begin{array}{l}\text { Total cultivable } \\
\text { bacteria (BacTot) }\end{array}$} & \multirow{2}{*}{$\begin{array}{l}\text { Urease } \\
\text { activity } \\
\text { (URE) }\end{array}$} & \multirow{2}{*}{$\begin{array}{l}\text { Alkaline } \\
\text { phosphatase } \\
\text { activity (AP) }\end{array}$} & \multirow[t]{2}{*}{$\begin{array}{l}\text { Aryl-sulfatase } \\
\text { activity (AS) }\end{array}$} & \multirow[t]{2}{*}{$\begin{array}{l}\text { Beta-glucosidase } \\
\text { activity }(\beta \mathrm{GLU})\end{array}$} & \multirow[t]{2}{*}{$\mathrm{pH}$} & \multicolumn{5}{|c|}{$\begin{array}{l}\text { Element concentration in } \\
\text { shoots of Alyssum murale }\end{array}$} & \multirow{2}{*}{$\begin{array}{l}\text { Shoot dry } \\
\text { biomass } \\
\text { (SDB) }\end{array}$} \\
\hline & & & & & & & $\mathrm{K}$ & $\mathrm{P}$ & $\mathrm{S}$ & $\mathrm{Ca}$ & $\mathrm{Ni}$ & \\
\hline BacTot & 1 & & & & & & & & & & & \\
\hline URE & 0.92 & 1 & & & & & & & & & & \\
\hline AP & -0.09 & 0.14 & 1 & & & & & & & & & \\
\hline AS & 0.05 & 0.16 & 0.35 & 1 & & & & & & & & \\
\hline$\beta \mathrm{GLU}$ & 0.13 & 0.39 & 0.78 & 0.32 & 1 & & & & & & & \\
\hline $\mathrm{pH}$ & 0.38 & 0.35 & 0.12 & -0.20 & 0.01 & 1 & & & & & & \\
\hline $\mathrm{K}$ & 0.52 & 0.41 & -0.34 & 0.08 & -0.08 & 0.27 & 1 & & & & & \\
\hline $\mathrm{P}$ & 0.29 & 0.21 & -0.24 & 0.20 & -0.14 & 0.13 & 0.75 & 1 & & & & \\
\hline $\mathrm{S}$ & 0.08 & 0.07 & -0.51 & 0.07 & -0.53 & 0.11 & 0.33 & 0.29 & 1 & & & \\
\hline $\mathrm{Ca}$ & 0.18 & 0.22 & 0.10 & -0.56 & -0.03 & 0.18 & -0.11 & -0.34 & 0.16 & 1 & & \\
\hline $\mathrm{Ni}$ & 0.44 & 0.45 & -0.20 & -0.27 & 0.05 & -0.35 & 0.38 & 0.16 & 0.01 & 0.34 & 1 & \\
\hline SDB & 0.73 & 0.73 & -0.16 & 0.02 & 0.05 & -0.1 & 0.43 & 0.07 & 0.09 & 0.25 & 0.82 & 1 \\
\hline
\end{tabular}

In bold and italic significant correlations at the respective 5 and $10 \%$ levels

fect Ni DTPA extractability nor phytoextraction. By contrast, $\mathrm{N}$ addition did not remarkably change the $\mathrm{pH}$ values.
The results obtained in this study indicated clearly that mineral $\mathrm{N}$ supply significantly improved $A$. murale growth under the different $\mathrm{Ni}$ additions tested (Ni40 and 
Ni80). These results are in accordance with the positive effect of mineral fertilization on $A$. murale observed in several studies on plant biomass production (Bani et al. 2015) on the relief of stress conditions (Álvarez-López et al. 2016). Chaney et al. (2007) showed that $A$. murale crop yields could reach at least 20 tons of dry biomass per hectare (equivalent to $400 \mathrm{~kg} \mathrm{Ni} \mathrm{ha}^{-1}$ ) after the application of mineral fertilizers (NPK), herbicide and the use of an appropriate irrigation management. Such results can be explained by the high needs of nitrogen by the hyperaccumulator plants (McNear et al. 2010; Liu et al. 2016; Kidd et al. 2017) and especially the species from the Brassicaceae family. The supply of $\mathrm{N}$ fertilizers improves plant dry weight but also the phytoextraction efficiency as shown for the $\mathrm{Cd}, \mathrm{Ni}$ and $\mathrm{Zn}$ hyperaccumulator Noccaea caerulescens (J.Presl \& C.Presl-Brassicaceae) due to the acidification of soil (Sirguey et al. 2006) and the Ni hyperaccumulator A. murale (Bani et al. 2015). However, there are obvious differences reported in plant biomass and metal accumulation by $N$. caerulescens according to the form of $\mathrm{N}$ supplied, i.e. $\mathrm{NH}_{4}{ }^{+}$or $\mathrm{NO}_{3}{ }^{-}$, the latter stimulating phytoextraction yield (Schwartz et al. 2003; Monsant et al. 2008). In our case, we supplied both forms as ammonium nitrate so we did not provoke such strong effects. Moreover, the results from this study confirmed the absence of a $\mathrm{Ni}$ dilution phenomenon in the aerial parts of $A$. murale when plant biomass increased. Nickel concentrations in plant tissues increased with biomass yield. However, the increase of soil $\mathrm{Ni}$ concentration had no significant effect on the production of plant dry biomass.

\section{Soil microbial activities}

The soil microbial community represents a sensitive bioindicator of the environmental alteration (Sinsabaugh et al. 2008). Therefore, any changes in soil properties resulting either from natural or anthropogenic activities (like adding fertilizer or heavy metals to the soil) could affect the functioning and composition of soil microorganisms and, as a consequence, those of plants. Our study highlighted that increasing $\mathrm{Ni}$ concentrations in the soil significantly reduced bacterial density as shown for other metals in several studies (Vásquez-Murrieta et al. 2006; Sobolev and Begonia 2008; Li et al. 2009; Klimek 2012). However, in our case if the increase in Ni bioavailability was significant, the final level was quite limited compared to strongly polluted soils or most ultramafic soils (Benizri and Kidd 2018).

$\beta$-glucosidase, urease, arylsulfatase and alkaline phosphatase activities, representative of $\mathrm{C}, \mathrm{N}, \mathrm{S}$ and $\mathrm{P}$ biogeochemical cycles, respectively, were determined in the rhizosphere soil in response to increasing soil $\mathrm{Ni}$ concentrations and mineral $\mathrm{N}$ supply. Heavy metals contamination could lower soil enzyme activities due to protein denaturation, forming a complex with the substrate, interacting with the residues involved in enzyme functions, or by reacting with the enzyme-substrate complex (Hemida et al. 1997). Concerning the activity of urease, our study revealed a decrease with higher $\mathrm{Ni}$ concentrations in soil as shown previously (Pattnaik and Equeenuddin 2016). More precisely, Xiao et al. (2017) indicated that urease activity was negatively correlated to the bioavailability of heavy metals in soils which is consistent with our findings as soils were artificially contaminated with highly available $\mathrm{Ni}$ salts.

Inversely to urease, our data showed non-significant variation of the three other soil enzyme activities $(\beta$ glucosidase, arylsulfatase and alkaline phosphatase) when the concentration of $\mathrm{Ni}$ in soil increased from 40 to $80 \mathrm{mg} \mathrm{kg}^{-1}$ (Fig. 5). Similarly, Pessoa-Filho et al. (2015) found that enzyme activities related to C, P and S cycles were not affected by high $\mathrm{Ni}$ concentrations, where the enzymatic activities were compared on three ultramafic sites with different concentrations of DTPAextractable $\mathrm{Ni}\left(5.20 ; 134\right.$ and $\left.603 \mathrm{mg} \mathrm{kg}^{-1}\right)$. The changes in soil microbiological functioning observed in their study were more related to organic matter content than to Ni availability. If Epelde et al. (2009) confirmed that metal pollution did not cause a clear inhibition of soil enzyme activities, other studies have shown a negative effect of heavy metals on those activities with different patterns according to the study (see Kandeler et al. 2000; Renella et al. 2005).

Concerning the effect of $\mathrm{N}$ fertilizer, this study revealed that mineral $\mathrm{N}$ supply can reduce the detrimental effect of $\mathrm{Ni}$ on soil microbial activity. Indeed, $\mathrm{N}$ addition consistently increased the total cultivable bacteria and urease activity in the rhizosphere, whatever the $\mathrm{Ni}$ concentration applied to the soil. It is possible that the positive effect of $\mathrm{N}$ fertilization on the bacterial cells number and urease was indirect through a better growth of $A$. murale plants, which in turn provided higher carbon stocks to the rhizosphere microflora. Previous works again showed contradictory effects of $\mathrm{N}$ application on the microbial biomass and enzymatic activities. Similarly to our study, Jinghua et al. (2005) found that a certain level of $\mathrm{N}$ concentration would increase bacterial density. In fact, $\mathrm{N}$ addition would improve root development and exudation by alleviating soil $\mathrm{N}$ limitation and thus increasing microbial biomass (Zhang et al. 2017). An acceleration of urease activity has been also revealed by several studies after $\mathrm{N}$ addition on nonpolluted soils (e.g. Guan et al. 2011): this could be attributed to the presence of different microorganism groups with contrasting responses to $\mathrm{N}$ addition.

In contrast to our finding, Geisseler and Scow (2014) have shown that $\mathrm{N}$ fertilization can significantly depress microbial biomass. This was also confirmed by a synthesis on 82 field studies revealing that $\mathrm{N}$ fertilization reduced the microbial biomass by an average of $15 \%$ (Treseder 2008). Also, Ajwa et al. (1999) found that $\mathrm{N}$ fertilization to the soil reduced the urease activity. In fact, $\mathrm{N}$ additions can repress the microbial production of urease in soils through the end products or by products formed from the microbial assimilation of excessive $\mathrm{N}$ (Saha et al. 2008). 
Practical consequences for the agromining technology

These results confirmed that fertilization improves biomass yield without reducing the $\mathrm{Ni}$ concentration in plants. They also clearly show that continuous agromining of Ni from natural soils is expected to improve the soil microbial fertility (e.g. urease activity) over the long term as it will decrease Ni availability. Fertilization has also the effect of enhancing soil microbial activity and therefore of decreasing the toxicity effect of $\mathrm{Ni}$ on soil bacteria.

The rate of Ni removal after one crop was $6 \%$ for the Ni40 treatment and $8 \%$ for the Ni80 treatment with $\mathrm{N}$ fertilization. Assuming that one hectare contains 3200 tons of arable soil $(0-20 \mathrm{~cm})$, the $\mathrm{Ni}$ yield per ha was $8 \mathrm{~kg} \mathrm{ha}^{-1}$ for the $\mathrm{N}$-fertilized $\mathrm{Ni40}$ treatment and $20 \mathrm{~kg} \mathrm{ha}^{-1}$ for the $\mathrm{N}$-fertilized Ni80 treatment with a 33 and $50 \%$, respectively due to $\mathrm{N}$ fertilization compared to non-fertilized treatments. In terms of practical consequences, this means that fertilization of agromining plots is a necessary condition to improve phytoextraction yield but also to improve soil biological fertility (an ecosystem service).

\section{Conclusion}

This study has confirmed that nitrogen application may improve the phytoextraction efficiency of $\mathrm{Ni}$ by enhancing both biomass yield and $\mathrm{Ni}$ concentration in shoots. The measurement of total cultivable bacteria has also confirmed the toxic effect of $\mathrm{Ni}$ contamination on both soil microbes and urease activity. However, the supply of nitrogen fertilizer could alleviate the negative effect of $\mathrm{Ni}$ on soil microbial activities. In fact, $\mathrm{N}$ fertilizer has ameliorated both the bacterial community and the urease activity in the rhizosphere of $A$. murale independently of the soil Ni content. This resulted in a better plant growth and a higher accumulation of $\mathrm{Ni}$ in the aerial part and a subsequent alleviation of soil $\mathrm{Ni}$ toxicity for microbes.

Acknowledgements We express our deep appreciation to the research grant programs of the Lebanese University and the Lebanese Council for Scientific Research, which provided funding for this project. We are also thankful to the French National Research Agency for their support through the national Investissements d'avenir program, reference ANR-10-LABX-21-LABEX RESSOURCES21 and through the ANR-14-CE04-0005 project Agromine. Finally, we are grateful to the technical team of Laboratoire Sols et Environnement and PRASE-Lebanese University for their help and support.

\section{References}

Abou Shanab RA, Angle JS, Delorme TA, Chaney RL, Van Berkum P, Moawad H, Ghanem K, Ghozlan HA (2003) Rhizobacterial effects on nickel extraction from soil and uptake by Alyssum murale. New Phytol 158:219-224. https://doi.org/10. 1046/j.1469-8137.2003.00721.x
Ajwa HA, Dell CJ, Rice CW, Rice CW (1999) Changes in enzyme activities and microbial biomass of tallgrass prairie soil as related to burning and nitrogen fertilization. Soil Biol Biochem 31:769-777. https://doi.org/10.1016/S0038-0717(98)00177-1

Álvarez-López V, Prieto-Fernández Á, Cabello-Conejo MI, Kidd PS (2016) Organic amendments for improving biomass production and metal yield of Ni-hyperaccumulating plants. Sci Total Environ 548-549:370-379. https://doi.org/10.1016/j.sci totenv.2015.12.147

Bani A, Echevarria G, Sulçe S, Morel JL, Mullai A (2007) In-situ phytoextraction of Ni by a native population of Alyssum murale on an ultramafic site (Albania). Plant Soil 293:79-89. https://doi.org/10.1007/s11104-007-9245-1

Bani A, Pavlova D, Echevarria G, Mullaj A, Reeves RD, Morel JL, Sulçe S (2010) Nickel hyperaccumulation by the species of Alyssum and Thlaspi (Brassicaceae) from the ultramafic soils of the Balkans. Bot Serbica 34:3-14

Bani A, Echevarria G, Sulçe S, Morel JL (2015) Improving the agronomy of Alyssum murale for extensive phytomining: a fiveyear field study. Int J Phytoremediation 17:117-127. https://doi. org/10.1080/15226514.2013.862204

Baudoin E, Benizri E, Guckert A (2003) Impact of artificial root exudates on the bacterial community structure in bulk soil and maize rhizosphere. Soil Biol Biochem 35:1183-1192. https://doi. org/10.1016/S0038-0717(03)00179-2

Bending GD, Turner MK, Rayns F, Marx MC, Wood M (2004) Microbial and biochemical soil quality indicators and their potential for differentiating areas under contrasting agricultural management regimes. Soil Biol Biochem 36:1785-1792. https://doi.org/10.1016/j.soilbio.2004.04.035

Benizri E, Kidd P (2018) The role of the rhizosphere and microbes associated with hyperaccumulator plants in metal accumulation. In: Van der Ent A, Echevarria G, Baker A, Morel JL (eds) Agromining: farming for metals - extracting unconventional resources using plants. Springer Nature AG, Cham, pp 157-188

Biney C, Amuzu AT, Calamari D, Kaba N, Mbome IL, Naeve H, Ochumba PB, Osibanjo O, Radegonde V, Saad MA (1994) Review of heavy metals in the African aquatic environment. Ecotoxicol Environ Saf 28:134-159. https://doi.org/10.1006/ eesa.1994.1041

Boyd RS, Jaffré T (2009) Elemental concentrations of eleven new caledonian plant species from serpentine soils: elemental correlations and leaf-age effects. Northeast Nat 16:93-110

Caldwell BA (2005) Enzyme activities as a component of soil biodiversity: a review. Pedobiologia 49:637-644. https://doi.org/10. 1016/j.pedobi.2005.06.003

Chaney RL, Angle JS, Broadhurst CL, Peters CA, Tappero RV, Sparks DL (2007) Improved understanding of hyperaccumulation yields commercial phytoextraction and phytomining technologies. J Environ Qual 36:1429-1443. https://doi.org/10. 2134/jeq2006.0514

Chaney RL, Chen KY, Li YM, Angle JS, Baker AJ (2008) Effects of calcium on nickel tolerance and accumulation in Alyssum species and cabbage grown in nutrient solution. Plant Soil 311:131-140. https://doi.org/10.1007/s11104-008-9664-7

Cunningham SD, Ow DW (1996) Promises and prospects of phytoremediation. Plant Physiol 110:715-719

Deng Y, He Z, Xu M, Qin Y, Van Nostrand JD, Wu L, Roe BA, Wiley G, Hobbie SE, Reich PB, Zhou J (2012) Elevated carbon dioxide alters the structure of soil microbial communities. Appl Environ Microbiol 78:2991-2995. https://doi.org/10.1128/ AEM.06924-11

do Nascimento CWA, Xing B (2006) Phytoextraction: a review on enhanced metal availability and plant accumulation. Sci Agric 63:299-311. https://doi.org/10.1590/S0103-90162006000300014

Duineveld BM, Kowalchuk GA, Keijzer A, van Elsas JD, van Veen JA (2001) Analysis of bacterial communities in the rhizosphere of chrysanthemum via denaturing gradient gel electrophoresis of PCR-amplified 16S rRNA as well as DNA fragments coding for 16S rRNA. Appl Environ Microbiol 67:172-178. https://doi.org/10.1128/AEM.67.1.172-178.2001 
Durand A, Piutti S, Rue M, Morel JL, Echevarria G, Benizri E (2016) Improving nickel phytoextraction by co-cropping hyperaccumulator plants inoculated by plant growth promoting rhizobacteria. Plant Soil 399:179-192. https://doi.org/10.1007/ s11104-015-2691-2

Egamberdieva D, Kucharova Z, Davranov K, Berg G, Makarova N, Azarova T, Chebotar V, Tikhonovich I, Kamilova F, Validov SZ, Lugtenberg B (2011) Bacteria able to control foot and root rot and to promote growth of cucumber in salinated soils. Biol Fertil Soils 47:197-205. https://doi.org/10.1007/s00374010-0523-3

Epelde L, Becerril JM, Alkorta I, Garbisu C (2009) Heavy metal phytoremediation: Microbial indicators of soil health for the assessment of remediation efficiency. Advances in applied bioremediation. Springer, Berlin, pp 299-313

García C, Roldán A, Hernández T (2005) Ability of different plant species to promote microbiological processes in semiarid soil Geoderma 124:193-202. https://doi.org/10.1016/j.geoderma. 2004.04.013

Geisseler D, Scow KM (2014) Long-term effects of mineral fertilizers on soil microorganisms - a review. Soil Biol Biochem 75:54-63. https://doi.org/10.1016/j.soilbio.2014.03.023

Glick BR (2010) Using soil bacteria to facilitate phytoremediation. Biotechnol Adv 28:367-374. https://doi.org/10.1016/j.bio techadv.2010.02.001

Guan G, Tu S, Yang J, Zhang J, Yang L (2011) A field study on effects of nitrogen fertilization modes on nutrient uptake, crop yield and soil biological properties in rice-wheat rotation system. Agric Sci China 10:1254-1261. https://doi.org/10.1016/ S1671-2927(11)60117-X

Hagmann J, Becker C, Müller J, Stegle O, Meyer RC, Wang G, Schneeberger K, Fitz J, Altmann T, Bergelson J, Borgwardt K (2015) Century-scale methylome stability in a recently diverged Arabidopsis thaliana lineage. PLoS Genet 11:e1004920. https://doi.org/10.1371/journal.pgen.1004920

Hemida SK, Omar SA, Abdel-Mallek AY (1997) Microbial populations and enzyme activity in soil treated with heavy metals. Water Air Soil Pollut 95:13-22. https://doi.org/10.1007/ BF02406152

Hinsinger P, Plassard C, Jaillard B (2006) Rhizosphere: a new frontier for soil biogeochemistry. $\mathbf{J}$ Geochem Explor 88:210-213. https://doi.org/10.1016/j.gexplo.2005.08.041

Jinghua X, Jiangming M, Jiong L (2005) Effects of nitrogen deposition on soil microorganism. Ecol Environ 14:777-782

Kandeler E, Tscherko D, Bruce KD, Stemmer M, Hobbs PJ, Bardgett RD, Amelung W (2000) Structure and function of the soil microbial community in microhabitats of a heavy metal polluted soil. Biol Fertil Soils 32:390-400. https://doi.org/10. $1007 / \mathrm{s} 003740000268$

Khan AG (2005) Role of soil microbes in the rhizospheres of plants growing on trace metal contaminated soils in phytoremediation. J Trace Elem Med Biol 18:355-364. https://doi.org/10.1016/j. jtemb.2005.02.006

Kibblewhite M, Ritz K, Swift M (2008) Soil health in agricultural systems. Philos Trans R Soc B Biol Sci 363:685-701. https://doi. org/10.1098/rstb.2007.2178

Kidd PS, Alvarez-López V, Becerra-Castro C, Cabello-Conejo M, Prieto-Fernández Á (2017) Chapter three-potential role of plant-associated bacteria in plant metal uptake and implications in phytotechnologies. In: Cuypers A, Vangronsveld J (eds) Advances in botanical research. Academic Press, Cambridge, pp 87-126

Klimek B (2012) Effect of long-term zinc pollution on soil microbial community resistance to repeated contamination. Bull Environ Contam Toxicol 88:617-622. https://doi.org/10.1007/ s00128-012-0523-0

Krumins JA, Goodey NM, Gallagher F (2015) Plant-soil interactions in metal contaminated soils. Soil Biol Biochem 80:224-231. https://doi.org/10.1016/j.soilbio.2014.10.011

Lasat MM (2002) Phytoextraction of toxic metals: a review of biological mechanisms. J Environ Qual 31:109-120
Li YT, Rouland C, Benedetti M, Li FB, Pando A, Lavelle P, Dai J (2009) Microbial biomass, enzyme and mineralization activity in relation to soil organic $\mathrm{C}, \mathrm{N}$ and $\mathrm{P}$ turnover influenced by acid metal stress. Soil Biol Biochem 41:969-977. https://doi.org/ 10.1016/j.soilbio.2009.01.021

Liu W, Zhang C, Hu P, Luo Y, Wu L, Sale P, Tang C (2016) Influence of nitrogen form on the phytoextraction of cadmium by a newly discovered hyperaccumulator Carpobrotus rossii. Environ Sci Pollut Res Int 23:1246-1253. https://doi.org/10. 1007/s11356-015-5231-y

Lopez S, Piutti S, Vallance J, Morel JL, Echevarria G, Benizri É (2017) Nickel drives bacterial community diversity in the rhizosphere of the hyperaccumulator Alyssum murale. Soil Biol Biochem 114:121-130. https://doi.org/10.1016/j.soilbio.2017.07.010

Ma Y, Rajkumar M, Freitas H (2009) Isolation and characterization of Ni mobilizing PGPB from serpentine soils and their potential in promoting plant growth and $\mathrm{Ni}$ accumulation by Brassica spp. Chemosphere 75:719-725. https://doi.org/10. 1016/j.chemosphere.2009.01.056

McNear DH, Chaney RL, Sparks DL (2010) The hyperaccumulator Alyssum murale uses complexation with nitrogen and oxygen donor ligands for Ni transport and storage. Phytochemistry 71:188-200. https://doi.org/10.1016/j.phytochem. 2009.10.023

Monsant AC, Tang C, Baker AJM (2008) The effect of nitrogen form on rhizosphere soil $\mathrm{pH}$ and zinc phytoextraction by $T h$ laspi caerulescens. Chemosphere 73:635-642. https://doi.org/10. 1016/j.chemosphere.2008.07.034

Naseby DC, Lynch JM (2002) Enzymes and microorganisms in the rhizosphere. Enzym Environ Act Ecol Appl Marcel Dekker N Y $109-123$

Pattnaik BK, Equeenuddin SM (2016) Potentially toxic metal contamination and enzyme activities in soil around chromite mines at Sukinda Ultramafic Complex, India. J Geochem Explor 168:127-136. https://doi.org/10.1016/j.gexplo.2016.06.011

Pessoa-Filho M, Barreto CC, dos Reis Junior FB, Fragoso RR, Costa FS, de Carvalho Mendes I, de Andrade LR (2015) Microbiological functioning, diversity, and structure of bacterial communities in ultramafic soils from a tropical savanna. Antonie Van Leeuwenhoek 107:935-949. https://doi.org/10. 1007/s10482-015-0386-6

Pulford ID, Watson C (2003) Phytoremediation of heavy metalcontaminated land by trees - a review. Environ Int 29:529-540. https://doi.org/10.1016/S0160-4120(02)00152-6

Renella G, Mench M, Landi L, Nannipieri P (2005) Microbial activity and hydrolase synthesis in long-term Cd-contaminated soils. Soil Biol Biochem 37:133-139. https://doi.org/10.1016/ j.soilbio.2004.06.015

Saad R, Kobaissi A, Robin C et al (2016) Nitrogen fixation and growth of Lens culinaris as affected by nickel availability: a prerequisite for optimization of agromining. Environ Exp Bot 131:1-9. https://doi.org/10.1016/j.envexpbot.2016.06.010

Saha S, Prakash V, Kundu S, Kumar N, Mina BL (2008) Soil enzymatic activity as affected by long term application of farm yard manure and mineral fertilizer under a rainfed soybeanwheat system in N-W Himalaya. Eur J Soil Biol 44:309-315

Schwartz C, Echevarria G, Morel JL (2003) Phytoextraction of cadmium with Thlaspi caerulescens. Plant Soil 249:27-35

Sinsabaugh RL, Lauber CL, Weintraub MN, Ahmed B, Allison SD, Crenshaw C, Contosta AR, Cusack D, Frey S, Gallo ME, Gartner TB (2008) Stoichiometry of soil enzyme activity at global scale. Ecol Lett 11:1252-1264. https://doi.org/10.1111/j. 1461-0248.2008.01245.x

Sirguey C, Schwartz C, Morel JL (2006) Response of Thlaspi caerulescens to nitrogen, phosphorus and sulfur fertilisation. Int J Phytoremediation 8:149-161. https://doi.org/10.1080/ 15226510600678498

Smalla K, Wieland G, Buchner A, Zock A, Parzy J, Kaiser S, Roskot N, Heuer H, Berg G (2001) Bulk and rhizosphere soil bacterial communities studied by denaturing gradient gel electrophoresis: plant-dependent enrichment and seasonal shifts revealed. Appl Environ Microbiol 67:4742-4751 
Sobolev D, Begonia MFT (2008) Effects of heavy metal contamination upon soil microbes: lead-induced changes in general and denitrifying microbial communities as evidenced by molecular markers. Int J Environ Res Public Health 5:450-456

Sowerby A, Emmett B, Beier C, Tietema A, Penuelas J, Estiarte M, Van Meeteren MJ, Hughes S, Freeman C (2005) Microbial community changes in heathland soil communities along a geographical gradient: interaction with climate change manipulations. Soil Biol Biochem 37:1805-1813. https://doi.org/10. 1016/j.soilbio.2005.02.023

Tabatabai MA, Bremner JM (1972) Assay of urease activity in soils. Soil Biol Biochem 4:479-487. https://doi.org/10.1016/ 0038-0717(72)90064-8

Tandy S, Healey JR, Nason MA, Williamson JC, Jones DL (2009) Heavy metal fractionation during the co-composting of biosolids, deinking paper fibre and green waste. Bioresour Technol 100:4220-4226. https://doi.org/10.1016/j.biortech.2009.02.046

Treseder KK (2008) Nitrogen additions and microbial biomass: a meta-analysis of ecosystem studies. Ecol Lett 11:1111-1120. https://doi.org/10.1111/j.1461-0248.2008.01230.x

Tumi AF, Mihailović N, Gajić BA, Niketić M, Tomović G (2012) Comparative study of hyperaccumulation of nickel by Alyssum murale sl populations from the ultramafics of Serbia. Pol J Environ Stud 21:1855-1866 van der Ent A, Baker AJ, Reeves RD, Pollard AJ, Schat H (2013) Hyperaccumulators of metal and metalloid trace elements: facts and fiction. Plant Soil 362:319-334. https://doi.org/10.1007/ s11104-012-1287-3

Vangronsveld J, Herzig R, Weyens N, Boulet J, Adriaensen K, Ruttens A, Thewys T, Vassilev A, Meers E, Nehnevajova E, van der Lelie D (2009) Phytoremediation of contaminated soils and groundwater: lessons from the field. Environ Sci Pollut Res Int 16:765-794. https://doi.org/10.1007/s11356-009-0213-6

Vásquez-Murrieta MS, Migueles-Garduño I, Franco-Hernández O, Govaerts B, Dendooven L (2006) C and N mineralization and microbial biomass in heavy-metal contaminated soil. Eur $\mathbf{J}$ Soil Biol 42:89-98. https://doi.org/10.1016/j.ejsobi.2005.10.002

Xiao L, Guan D, Peart MR, Chen Y, Li Q, Dai J (2017) The influence of bioavailable heavy metals and microbial parameters of soil on the metal accumulation in rice grain. Chemosphere 185:868-878. https://doi.org/10.1016/j.chemosphere. 2017.07.096

Zhang J, Ai Z, Liang C, Wang G, Xue S (2017) Response of soil microbial communities and nitrogen thresholds of Bothriochloa ischaemum to short-term nitrogen addition on the Loess Plateau. Geoderma 308:112-119. https://doi.org/10.1016/j.geo derma.2017.08.034 